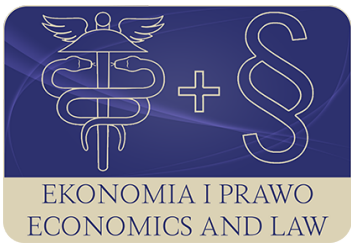

EKONOMIA I PRAWO. ECONOMICS AND LAW

Volume 19, Issue 1, March 2020

p-ISSN 1898-2255, e-ISSN 2392-1625

www.economicsandlaw.pl

ORIGINAL ARTICLE

received 30.03.2019; revised 03.01.2020; accepted 31.03.2020

Citation: Charłampowicz, J., \& Mańkowski, C. (2020). Economic efficiency evaluation system of maritime container terminals. Ekonomia i Prawo. Economics and Law, 19(1): 21-32. doi:10.12775/EiP.2020.002.

\title{
Economic efficiency evaluation system of maritime container terminals
}

\author{
JĘDRZEJ CHAREAMPOWICZ \\ corresponding author \\ Gdynia Maritime University, Faculty of Entrepreneurship and Quality Science, Department \\ of Logistics and Transport Systems, ul. Morska 81-87, 81-222 Gdynia, Poland \\ $\square$ j.charlampowicz@wpit.umg.edu.pl \\ (D) orcid.org/0000-0002-3140-4679
}

CEZARY MAŃKOWSKI

University of Gdańsk, Faculty of Economics, Department of Logistics, Poland

$\square$ cezary.mankowski@ug.edu.pl

(D) orcid.org/0000-0001-5496-0507

\begin{abstract}
Motivation: Maritime container terminals play an important role in global as well as local supply chains. Especially, maritime container terminals can be perceived as essential transhipment points, which integrate other transport modes through a set of management

(e.g. planning, controlling) and executive activities (e.g. reloading, handling). All these activities require the support of an adequate management system, focusing on continuous improvement of the maritime container economic efficiency. To meet this requirement an economic efficiency evaluation system is needed, which will be responsible for the assessment of maritime container terminals' activities, mainly according to such economic criteria as time and cost efficiency. In the literature some papers can be found, which are focused on the technical efficiency evaluation systems for the maritime container terminals based on parametrical methods. However, the literature does not cover the problem of proper economic efficiency evaluation system, designed for maritime container terminals.

Aim: Based on the above mentioned reasons, the purpose of the article is to develop a system of economic efficiency evaluation for maritime container terminals.

Results: Based on the research findings a conceptual model of economic efficiency evaluation system for the maritime container terminals is presented in the article.
\end{abstract}


Keywords: maritime container terminal; economic efficiency evaluation system; cost efficiency; time efficiency

JEL: B27; M00; R40

\section{Introduction}

Global supply chains are very complicated structures, where the maritime container shipping market plays an important role (see: Panayides, 2006, p. 6; Song \& Panayides, 2008, p. 75). From a geographical point of view the maritime transport is the longest link of global chains (Charłampowicz, 2018b, p. 363). Moreover, the maritime container shipping market has become more concentrated on the supply side of the market (Charłampowicz, 2018a, p. 376), which has an influence on competitiveness of the above mentioned and other related markets. A maritime container terminal, which is one of the transhipment points, can be perceived as an essential node, which integrates other transport modes. This integration is expressed in two forms: as a set of management activities, such as e.g. planning and controlling, and as a set of executive activities, which includes handling, reloading, warehousing of containers etc. The operations taking place at the maritime container terminals are crucial in terms of supply chain efficiency. To manage these operations, in terms of continuous efficiency improvement, an adequate management system is needed, which consequently requires a subsystem focused on the assessment of the terminals' activities in terms of efficiency, which is to say to cost and time criteria.

Even though the problem of technical efficiency of maritime container terminal is widely analysed (see e.g.: Almawsheki \& Shah, 2015; Cullinane et al., 2002; Jiang \& Li, 2009; Kutin et al., 2017; Tongzon, 2001; Zheng \& Park, 2016), and some researchers focus on developing port performance indicators (Di Vaio et al., 2018), technical port efficiency (Lopez-Bermudez et al., 2019) or decision support tools for container terminals (Kapetanis et al., 2016), there is a lack of proper models for overall economic efficiency evaluation in the literature.

Therefore, taking into account the above assumptions, the aim of this paper is to develop a system of economic efficiency evaluation for maritime container terminals.

The above stated purpose is carried out through a research process, which covers such research methods as a critical literature review supported by methods of logical reasoning (reduction, induction, deduction), and methods, which are oriented towards the modelling of economic systems, including a conceptual model of the proposed system in the graphic form of a block scheme.

The content of this paper is divided as follows. Section 2 provides the literature review on maritime container terminals efficiency. Section 3 describes the research methodology. Section 4 presents the conceptual model for economic efficiency evaluation of maritime container terminals. Section 5 demonstrates discussion. Section 6 includes conclusions. 


\section{Literature review concerning maritime container terminals efficiency}

According to WTO (2017, p. 11), transport, as an exported commercial service, has a $17.7 \%$ of share commercial services (other services are: goods-related services, travel and other commercial services). Transport as an imported commercial service has a $21.8 \%$ share. The average increase in the sea freight during the period 2005-2016, in million loaded tones, was 5.2\%. In 2016 global containerized trade expanded by $3.2 \%$ year-to-year, with volumes reaching 140 million TEU's (UNCTAD, 2017, p. 11). General cargo accounts for around 60\% of the global value of shipped goods, which most of them are transported by containerized liner services (Stopford, 2009, p. 505). The proper management of container terminals is crucial for achieving a high level of efficiency, particularly seen from the terminal's point of view and, the wider, supply chain perspective. Port management issues have been widely examined in the literature (e.g.: Cullinane et al., 2002; Meisel, 2009; Urbanyi-Popiołek \& Klopott, 2016), although there is a gap in the knowledge connected with the economic efficiency of the maritime terminals, including container ones. As they are defined as complex structures, which are focused mainly on the performance of a variety of operations with the flow of containers through the maritime transportation chain (Alyami et al., 2019, p. 411), they are also business units aimed to provide a profit for its stakeholders. Thus, in order to fulfil this purpose, the maritime container terminals are obliged to obtain high levels of efficiency.

Efficiency is usually understood as a relation between effects and the amount of resources used for achieving these effects (see Samuelson \& Nordhaus, 2009, pp. 13-14). The most applied kind of efficiency is a technical or exploitation efficiency understood as an ability to handle more containers (see e.g.: Almawsheki \& Shah, 2015; Kutin et al., 2017). This simple definition is extended by other researchers. For instance, Cullinane et al. (2002) conducted a research based on stochastic frontier analysis method to examine the relation between terminal efficiency, its size and the type of ownership. Output variable was annual container throughput in TEU, and input variables were: terminal quay length, terminals area and number of cargo handling equipment. The sample comprised 15 container ports and terminals in Asia. This report proved that the size and private type of ownership have got a positive influence on the efficiency. In another research, Cullinane \& Song (2006) confirmed also the positive relation between port size and its efficiency. Perez et al. (2016) conducted a research based on a stochastic frontier to examine the efficiency container terminals in Latin America and the Caribbean countries. Output variable was container throughput in TEU, and input variables were quay length, storage area and number of cranes. The results show that ports with three or four terminals are the most efficient while transhipment ports are less efficient. Almawsheki \& Shah (2015) examined 19 container terminals located in the Middle-East region, and based on DEA (Data Envelopment Analysis) method they show that almost 
$85 \%$ of terminals are inefficient. They used output variable, which was container throughput in TEU and five input variables: terminal area, quay length, number of quay cranes, number of yard equipment and maximum draft. The main weakness of this study lays in the fact that it is based on a single-period data. A lack of the possibility to capture the dynamics of efficiency over the years is a great limitation of this research. Similar limitation can be found in research conducted by Zheng \& Park (2016). They used four input variables, which were: berth length, yard area, number of quay cranes and number of yard cranes, and the output variable was also the container throughput. Their study showed that the efficiency of major Korea terminals are similar to those in China, which was contrary to the results of their previous studies (see Zheng \& Park, 2016, p. 219). Kutin et al. (2017) conducted research of relative efficiencies of ASEAN container ports based on DEA method. They divided examined terminals into six categories in reference to their characteristics and equipment. For the most extensive lst category, seven input variables were used while in other categories the input number was adjusted to the number of DMU's (Decision Making Units) (see Kutin et al., 2017, p. 71). The output variable was container throughput. This study shows that ASEAN ports reach a relatively good level of efficiencies and can handle more container volume than the others, although this research was using single-period data. Research conducted by Jiang \& Li (2009) focused on a technical efficiency of maritime containers of Japan, China and Korea. During their research they proposed a scheme for the estimation this kind of efficiency as a performance measure through the application of a radial and non-radial DEA approach. In this research, scientists specified one output variable (TEU throughput) and four input variables (import/export by customs, GDP by region, berth length, crane numbers). The obtained results show that Korean and Chinese container terminals are mostly efficient on a similar level (see Jiang \& Li, 2009, p. 231). Ding et al. (2015) performed a research of a relative efficiency of 21 small and medium sized coastal container terminals in China. Their research process embraced 2 stages. First one was carried out using DEA and the Malmquist Productivity Index, and the second one, which included estimation and quantification of factors affecting productivity, was made using Tobit regression. It was reported as a final research result that the cooperation with hub ports was the main method for improving these terminals efficiency (Ding et al., 2015, p. 247). Wiegmans \& Witte (2017) examined the efficiency of the inland waterway container terminals using two methods, parametrical (i.e. stochastic frontier analysis) and non-parametrical (i.e. DEA). They defined eight input variables (working hours, terminal area, stacking yard in TEU, quay length, draught, number of cranes, number of reach stackers and annual handling capacity) and two output variables (annual handling capacity and container throughput), where the handling capacity was a design efficiency and the throughput was the operational efficiency of the inland waterway container terminals. The research proved that identification of the input variables is crucial to define the efficiency level and the efficiency of the in- 
land waterways container terminals differed from the efficiency of maritime container terminals (see Wiegmans \& Witte, 2017, p. 19). Finally, it worthy to quote a research carried out by Bichou (2013), who confirmed that variations in operating conditions, such as e.g. yard storage policy or the gate operating procedure, have got a direct impact on the terminal's efficiency, and a research of Kaselimi et al. (2011), who analysed relations between technical, market-related and governance-related factors, and preferred container terminal scales.

The above reviewed research prove the technical efficiency is of course related to the economic one as long as it allows maritime container services to be efficient economically through the ability to perform technical operations smoothly, and especially if it leads to the increase of the economic efficiency, for instance through decreasing cost and time of operations. Therefore, the time and cost (economic) related efficiency of maritime container terminals should be also taken as a subject for comprehensive research.

Since the maritime container terminals have got an important place in the economy, its overall economic efficiency can be measured by its share in GDP (see Matczak, 2016, p. 27). However, to assess the efficiency of these terminals for decision making (managerial) purposes, it is necessary to develop a suitable evaluation system for the managed objects, i.e. maritime container terminals. Although, the above reviewed literature concerning technical efficiency of these terminals is rather extensive, there is not much devoted to the economic efficiency. Especially, there is no existence of a model of economic efficiency evaluation for maritime container terminals. Therefore, it is crucial to develop one.

\section{Methods}

To meet the aim of this paper, this is to develop a system of economic efficiency evaluation for maritime container terminals, the following methodological approach is proposed. At the starting point two assumptions are formulated as:

- if the research aim is to develop a system, the main methodology idea should be based on the general system theory;

- if the aim of the system is to evaluate economic efficiency of maritime container terminals, which is a managerial task, the management theory is the right scientific discipline to look for more detailed conceptions to build the system structure.

According to the inventor of the general system theory, 'a system can be defined as a set of elements standing in interrelations' (Bertalanffy, 1984, p. 55). For very few applications of this general system theory it is enough to distinguish only two parts of the system. i.e. complex (wholeness) and elements, including relations. For highly complex social and economic systems, which are characterized by a large amount of elements (or subsystems), which consist of smaller elements (or sub-subsystems), correlated often in a very sophisticated way, a perception of a system as a holon is proposed. According to the holonism 
inventor, 'organisms and societies are multi-levelled hierarchies of semi- autonomous sub-wholes branching into sub-wholes of a lower order, and so on. The term <holon> has been introduced to refer to these intermediary entities which, relative to their subordinates in the hierarchy, function as self-contained wholes; relative to their superordinates as dependent parts' (Koestler, 1968, p. 58). It means that the system of economic efficiency evaluation for maritime container terminals should be perceived as a multilevel hierarchical holon, which is a subsystem of a higher level system, for instance a management system of container terminals, and at the same time it is a system, which consists of subsystems (or elements). Because the main methodological task is to develop the structure of the system, thus there is a need to extend the general system theory by a conception on how our world is constructed. This is the ontology, which proposes to view the world as a set of events, processes, things and relations, and what seems to be very valuable proposition if applied to the system structure designing purposes, especially (see Mańkowski, 2007, p. 32). Next conception, which can be used to detail the four ontologies through the identification of the right names for the events, processes, thing and relations of the system; is the previously mentioned management theory. In the literature, a common view is maintained that the management system embraces four modules. They are planning, organizing, leading, and controlling (see Griffin, 2013, p. 7). However, for the purpose to evaluate the economic efficiency of maritime container terminals, the four subsystems need to be little changed. Particularly, it is essential to develop a proper plan of evaluating the efficiency of maritime container terminal activities, and the execution of the plan should be put under continuous control. However, to develop such a plan and control its execution, it is necessary to identify a set of indicators, which are usually multi-correlated and difficult to forecast.

Therefore, the above course of reasoning leads the authors of the article to put a hypothesis, which states that the proposed system of maritime container terminal economic efficiency evaluation should consist of mutually related modules (subsystems) of forecasting, correlation, planning, and control.

\section{Conceptual model of the economic efficiency evaluation system for maritime container terminals}

A conceptual model of the economic efficiency evaluation system for maritime container terminals is proposed as a holon structure in the sense it is a subsystem of a higher level system of management (lst level), and simultaneously as a system that consists of subsystems or modules (2nd level), which include sub-subsystems or sub-modules (3rd level). The above mentioned system structure on the 2nd and 3rd level, i.e. modules and sub-modules, is presented in scheme 1 .

The proposed model of the economic efficiency evaluation system for maritime container terminals consists of four modules: 
- planning,

- correlation,

- control tower,

- forecasting.

The planning module is proposed to contain crucial managerial and operational information for strategic, tactical and operational level. This module should integrate various information and data regarding numerous subjects. The planning module includes some sub-modules. First one is a sub-module of economic issues such as demand, customer needs, competition and human resources management, planned in time-cost space. The above mentioned information can be used for a development of the plan of maritime container terminals' operations on the strategic and tactical level. The next sub-module (within the planning module) regards technical and technological issues. These topics include information about the maintenance of terminals' equipment as well as ICT systems, equipment utilization degree, prices of new and used equipment, demand and supply of cargo handling equipment, usage and repair costs. Another important issue among technical and technological sub-module is a terminal work organization, which can be divided into three categories: gate policy, terminal route planning, and organization of storage facilities. This information can be useful during the development of plans for strategic, tactical and operational level. Last identified sub-module (within the planning module) is the operational level, which contains two elements: work organizations of physical employees and work organization of administrative and managerial staff. Physical employees are all employees working out of office at the maritime container terminals. Work organization should include the labour division with specific tasks.

Shifting into the next module in the economic efficiency evaluation system of maritime container terminal, namely the module of correlation between indicators, it is important, particularly for planning purposes, to acquire the information about correlations between indicators and their change impact on other indicators (e.g. high prices of new cargo handling equipment can lower the ability to invest in tangible assets, which can affect and decrease economic efficiency, due to the worse condition of equipment, lower demand, loss of a competitive power and a drop in the income). In addition, the correlation between indicators should be found in time and cost dimensions with respect to strategic, tactical and operational plans. Therefore, this module is proposed to include all the activities, which are focused on the identification of correlation coefficients, which are needed to construct the so-called correlation tables for 'what-if analysis', especially, for instance, of how much 'on time in full' (OTIF) indicator would change, if a maritime container terminal's 'overall equipment efficiency' (OEE) indicator changed by $1 \%$, etc.? Thus, within the correlation module, two sub-modules are identified in the form of a sub-module of variable parameterisation and a sub-module of correlation analysis. 
The next assistance for planning purposes comes from the third module, containing forecasting methods and tools, for which more detailed explanations are not needed. However, if the forecasting module is to be useful for strategic, tactical, and operational purposes, it should be divided into three sub-modules with the same names.

The last but not least module is the controlling one, which can also be named as a controlling tower, to indicate its measuring, variance analysis, and correction decision power related to maritime container terminals' activities to increase their economic efficiency. Because the decision areas for eventual corrections can be found at every previously mentioned modules (for instance in the case of unrealistic plans, wrong correlations or forecasts), these are the reasons why controlling module is related to all the other modules. Three sub-modules, which are responsible for a continuous control of the performance of strategic, tactical and operational objectives, consist on the controlling module. Every essential variance between the planned and actual indicators should be analyzed and corrected properly, based on the results of variance analysis. All the controlling sub-modules should assure maritime container terminals' ability to an agile adaptation to dynamically changing internal and external conditions.

\section{Discussion}

The above presented model is a conceptual one, which gives the advantage of generalization thus a longer life cycle and broader application possibilities over the other literature propositions. On the other hand, its disadvantages can be perceived in terms of the requirement of suitable indicators for measuring the specific elements of maritime container terminals' economic efficiency, what can be difficult from an application point of view. Therefore the developments of those indicators should be based on specific terminal characteristics and should be applicable on a global level for other entities. Another important issue is the problem of the determination of exact measures in all sub-modules. As the reviewed literature research results indicate, the proposed set of measurements can differ in relation to the specific activities of each maritime container terminal.

Although, as the reviewed literature indicates, some research is related to container terminal productivity and efficiency (see e.g.: De Oliveira \& Carriou, 2015; Wilmsmeier et al., 2013), this paper's contribution is a comprehensive proposition of an overall model of economic efficiency evaluation system designed for maritime container terminals.

\section{Conclusion}

Based on the literature review a gap has been identified in the knowledge concerning the relationship between technical, operational and economic issues regarding the efficiency of terminals. Most papers focused on the technical effi- 
ciency analysis (see e.g.: Almawsheki \& Shah, 2015; Jiang \& Li, 2009) or a relation between different types of efficiencies (see e.g.: Bichou, 2013; Kaselimi et al., 2011), but there is no research introducing an overall economic efficiency model. This paper has made an attempt to fill this gap by developing an original method of economic efficiency evaluation for maritime container terminals.

The presented model of efficiency evaluation of maritime container terminals should be confronted with the economic reality expressed in the form of an implementation of this model to an existing maritime container terminal. The results of this action would be very useful in terms of the managerial as well as the scientific point of view. Another research direction of great importance is the further development of this model in terms of specific indicators for every category of the presented sub-modules and verification of those indicators with maritime container terminal real business processes.

The lack of possibility of acquiring empirical data concerning specific terminal strategy, which includes plans, objectives and plans achievement at strategical, tactical and operational levels, greatly limits the ability of the presented model to confront with economic reality.

Therefore, based on the research findings, the main conclusions can be stated as follows:

- the proposed model offers the possibility to assess the economic efficiency of maritime container terminals more accurately and reliably than other solutions;

- there is a need for empirical verification of the proposed model based on real data and development of specific indicators (verified with real data) for every category of the presented sub-modules.

\section{References}

Almawsheki, E.S., \& Shah, M.Z. (2015). Technical efficiency analysis of container terminals in the middle eastern region. The Asian Journal of Shipping and Logistics, 31(4). doi:10.1016/j.ajsl.2016.01.006.

Alyami, H., Yang, Z., Riahi, R., Bonsall, S., \& Wang, J. (2019) Advanced uncertainty modelling for container port risk analysis. Accident Analysis \& Prevention, 123. doi:10.1016/j.aap.2016.08.007.

Bertalanffy, L. (1984). General system theory: foundations, development, applications. New York: Braziller.

Bichou, K. (2013). An empirical study of the impacts of operating and market conditions on container-port efficiency and benchmarking. Research in Transportation Economics, 42(1). doi:10.1016/j.retrec.2012.11.009.

Charłampowicz, J. (2018a). Market concentration of strategic alliances members in the maritime container shipping market on trade lanes passing across the Atlantic and the Pacific: selected issues. In O. Cokorilo (Ed.), Proceedings of the 4th International Conference on Traffic and Transport Engineering. Belgrade: City Net Scientific Research Center. 
Charłampowicz, J. (2018b). Supply chain efficiency on the maritime container shipping markets: selected issues. In D. Dujak, \& J.J. Strossmayer (Eds.), Business logistics in modern management: proceedings of the 18th International Scientific Conference. Osijek: Josip Juraj Strossmayer University of Osijek, Faculty of Economics in Osijek.

Cullinane, K., \& Song, D.-W. (2006). Estimating the relative efficiency of European container ports: a stochastic frontier analysis. Research in Transportation Economics, 16. doi:10.1016/S0739-8859(06)16005-9.

Cullinane, K., Song, D.-W., \& Gray, R. (2002). A stochastic frontier model of the efficiency of major container terminals in Asia: assessing the influence of administrative and ownership structures. Transportation Research Part A: Policy and Practice, 36(8). doi:10.1016/S0965-8564(01)00035-0.

De Oliveira, G.F., \& Cariou, P. (2015). The impact of competition on container port (in)efficiency. Transportation Research Part A: Policy and Practice, 78. doi:10.1016/j.tra.2015.04.034.

Di Vaio, A., Varriale, L., \& Alvino, F. (2018). Key performance indicators for developing environmentally sustainable and energy efficient ports: evidence from Italy. Energy Policy, 122. doi:10.1016/j.enpol.2018.07.046.

Ding, Z.-Y., Jo, G.-S., Wang, Y., \& Yeo, G.-T. (2015). The relative efficiency of container terminals in small and medium-sized ports in China. The Asian Journal of Shipping and Logistics, 31(2). doi:10.1016/j.ajsl.2015.06.004.

Griffin, R. (2013). Management. Mason: South-Western Cengage Learning.

Jiang, B., \& Li, J. (2009). DEA-based performance measurement of seaports in NorthEast Asia: radial and non-radial approach. The Asian Journal of Shipping and Logistics, 25(2). doi:10.1016/S2092-5212(09)80003-5.

Kapetanis, G.N., Psaraftis, H.N., \& Spyrou, D. (2016). A simple synchro: modal decision support tool for the Piraeus container terminal. Transportation Research Procedia, 14. doi:10.1016/j.trpro.2016.05.403.

Kaselimi, E.N., Notteboom, T.E., Pallis, A.A., \& Farrell, S. (2011). Minimum efficient scale (MES) and preferred scale of container terminals. Research in Transportation Economics, 32(1). doi:10.1016/j.retrec.2011.06.006.

Koestler, A. (1968). The ghost in the machine. New York: Macmillan.

Kutin, N., Nguyen, T.T., \& Vallee, T. (2017). Relative efficiencies of ASEAN container ports based on data envelopment analysis. The Asian Journal of Shipping and Logistics, 33(2). doi:10.1016/j.ajsl.2017.06.004.

Lopez-Bermudez, B., Freire-Seoane, M.J., \& Nieves-Martinez, D.J. (2019). Port efficiency in Argentina from 2012 to 2017: an ally for sustained economic growth. Utilities Policy, 61. doi:10.1016/j.jup.2019.100976.

Mańkowski, C. (2007). Ontological foundation for business logistic process modelling. Railway Transport and Logistics, 2(3).

Matczak, M. (2016). Raport: polskie porty morskie jako biegun rozwoju gospodarczego kraju i regionów lokalizacji. Retrieved 02.01.2020 from http:// www.bct.gdynia.pl. 
Meisel, F. (2009) Seaside operations planning in container terminals. Berlin: Physica-Verlag.

Panayides, P.M. (2006). Maritime logistics and global supply chains: towards a research agenda. Maritime Economics \& Logistics, 8(1). doi:10.1057/palgrave.mel.9100147.

Perez, I., Trujillo, L., \& Gonzalez, M.M. (2016). Efficiency determinants of container terminals in Latin American and the Caribbean. Utilities Policy, 41. doi:10.1016/j.jup.2015.12.001.

Samuelson, P., \& Nordhaus, W. (2009). Economics. New York: McGraw Hill. Song, D.-W. \& Panayides, P.M. (2008). Global supply chain and port/terminal: integration and competitiveness. Maritime Policy \& Management, 35(1). doi:10.1080/03088830701848953.

Stopford, M. (2009). Maritime economics. London-New York: Routledge.

Tongzon, J. (2001). Efficiency measurement of selected Australian and other international ports using data envelopment analysis. Transportation Research Part A: Policy and Practice, 35(2). doi:10.1016/S0965-8564(99)00049-X.

UNCTAD. (2017). Review of maritime transport 2017. Retrieved 02.01.2020 from https://unctad.org.

Urbanyi-Popiołek, I., \& Klopott, M. (2016). Container terminals and port city interface: a study of Gdynia and Gdańsk ports. Transportation Research Procedia, 16. doi:10.1016/j.trpro.2016.11.049.

Wiegmans, B., \& Witte, P. (2017). Efficiency of inland waterway container terminals: stochastic frontier and data envelopment analysis to analyze the capacity design- and throughput efficiency. Transportation Research Part A: Policy and Practice, 106. doi:10.1016/j.tra.2017.09.007.

Wilmsmeier, G., Tovar, B., \& Sanchez, R.J. (2013). The evolution of container terminal productivity and efficiency under changing economic environments. Research in Transportation Business \& Management, 8. doi:10.1016/j. rtbm.2013.07.003.

WTO. (2017). World trade statistical review 2017. Retrieved 02.01.2020 from https://www.wto.org.

Zheng, X.B., \& Park, N.K. (2016). A study on the efficiency of container terminals in Korea and China. The Asian Journal of Shipping and Logistics, 32(4). doi:10.1016/j.ajsl.2016.12.004.

\section{Acknowledgements}

Author contributions: authors have given an approval to the final version of the article. Authors contributed to this work equally.

Funding: this research was undertaken as part of The impact of container terminal management models on the efficiency of the supply chain project and was fully funded by a grant (WPIT/2019/PI/07).

Note: the results of this study were presented at 10th International Conference on Applied Economics Contemporary Issues in Economy (June 27-28, 2019, Torun, Poland). 


\section{Appendix}

\section{Scheme 1 .}

Conceptual model of the economic efficiency evaluation system for maritime container terminals

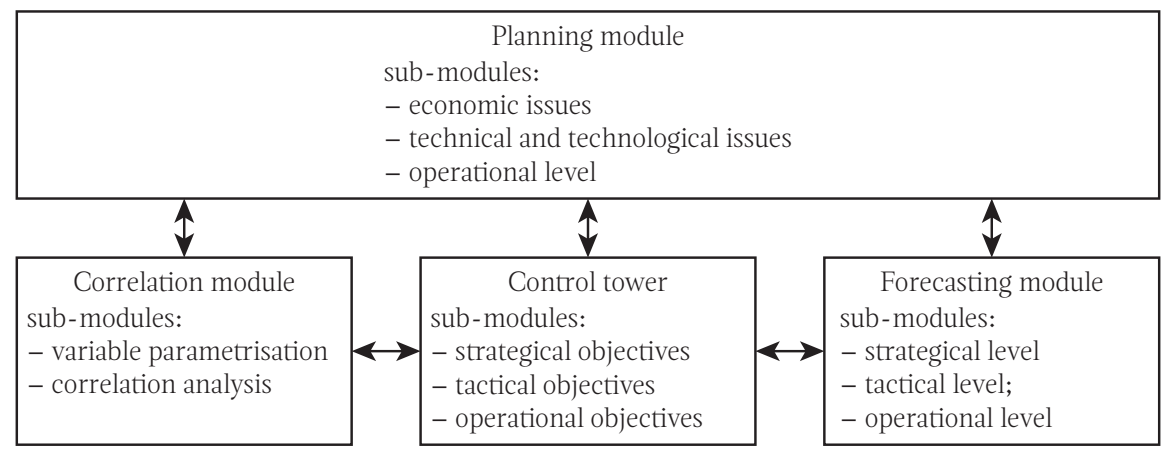

Source: Own preparation. 